\title{
Anti-Inflammatory, Analgesic and Antipyretic Activity of Catunaregam spinosa (Thumb.) Tirveng Extracts
}

\author{
Hansa Saini 1*, Jayesh Dwivedi ${ }^{2}$, Himanshu Paliwal ${ }^{3}$, Udichi Kataria ${ }^{4}$, Priyanka Chauhan ${ }^{2}$, Rahul Garg 5 \\ ${ }^{1}$ Department of Pharmacy, Bhagwant University, Ajmer, Rajasthan (India) \\ 2 Pacific College of Pharmacy, Pacific University, Udaipur, Rajasthan (India) \\ ${ }^{3}$ Sunrise College of Pharmacy, Udaipur, Rajasthan (India) \\ ${ }^{4}$ Geetanjali Institute of Pharmacy, Udaipur, Rajasthan (India) \\ ${ }^{5}$ Venkateshwar Institute of Pharmacy, Udaipur, Rajasthan (India)
}

\begin{abstract}
Catunaregam spinosa leaves have been ethnopharmacologically accounted for acquiring various pharmacological properties. The present study was undertaken to evaluate anti-inflammatory, analgesic and antipyretic potential of leaves of $C$. spinosa.The ethanolic extract was selected for this purpose based on phytochemical screening. Inflammation was inhibited at the dose of $200 \mathrm{mg} / \mathrm{kg}$ with percent inhibition of inflammation $32.06,37.28$ and $43.16 \%$, respectively, at 1,3 and $5 \mathrm{~h}$, while in egg albumin model \% inhibition was found to be $47.81 \%$. There was no significant analgesic activity seen in acetic acid induced writhing response method while significant effects were observed in the doses of 25 and $100 \mathrm{mg} / \mathrm{kg}$ on hot plate test. No antipyretic activity was shown by ethanolic extracts(25, 100 and $200 \mathrm{mg} / \mathrm{kg})$ against Brewer's yeast induced pyrexia in rats.
\end{abstract}

Keywords: Catunaregam spinosa, Anti-inflammatory activity, Phytochemical screening, Ethanolic extract.

Article Info: Received 10 June 2019; Review Completed 18 Aug 2019; Accepted 29 Aug 2019; Available online 15 Sep 2019

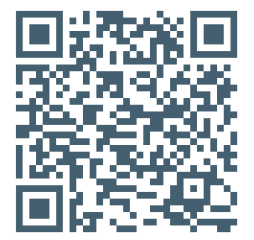

Cite this article as:

Saini H, Dwivedi J, Paliwal H, Kataria U, Chauhan P, Garg R, Anti-Inflammatory, Analgesic and Antipyretic Activity of Catunaregam spinosa (Thumb.) Tirveng Extracts, Journal of Drug Delivery and Therapeutics. 2019; 9(5):89-94 http://dx.doi.org/10.22270/jddt.v9i5.3363

Ms. Hansa Saini (M. Pharm.), Sikar Road, Ajmer-305004, Rajasthan (INDIA)

\section{INTRODUCTION}

Ever since ancient times, in search of rescue for their disease, the people looked for drugs in nature. According to the World Health Organisation (WHO), more than $80 \%$ of the World's population relies on traditional herbal medicine for their primary health care needs. In last few years interest of researches in medicinal plants has increased significantly. Identification and validation of plant derived substances for the management of several diseases is the goal of current researchers. It is estimated that about $25 \%$ of the western medicines are directly or indirectly derived from plant sources ${ }^{1}$.

Catunaregam spinosa (Thumb.) Tirveng is also known as a Randia dumetorum belongs to family Rubiaceae. It occurs in almost throughout India up to $4,000 \mathrm{ft}$ attitude 2,3 . C. spinosa is known to show alexiteric and antipyretic activity with also significant in skin diseases, inflammations, ulcers, wounds and tumours like diseases ${ }^{4}$. It contains secondary metabolites like triterpenoidal saponins, tannins, essential oil, resin and veleric acid. A number of Phytoconstituents are reported like D-mannitol, 1-keto-3 $\alpha$ hydroxy Oleanane, saponins, scopoletin, iridiodal and glycosides, such as garenoside, randioside and geniposide. Also, steroids and fatty acid such as caprlic acid, capric acid, tauric acid, myristic acid has been reported in literature 5,6 . The main aim of the current study is to to explore presence of phytochemical and secondary metabolites profile analysis of C. spinosa leaves and investigate the anti-inflammatory, analgesic and antipyretic activity of the plant.

\section{METHODOLOGY}

\section{Collection of plant material and authentication}

The leaves of the $C$. spinosa were collected and dried. The dried material was powdered in the coarse powder by mechanical grinder. The resulting coarse powder was used for the studies. The leaves of the plant were authenticated by the Dr. Dilip Gena, Botanist, Pteridophyte biology lab Department of Botany, Government College, Ajmer. 


\section{Extraction procedure for collected plant material}

The extract of leaves of Catunaregum spinosa was obtained different types of solvents like, Methanol, Ethanol, Acetone, Petroleum ether, Benzene and Distilled water. $10 \mathrm{gm}$ of powdered leaves of $C$. spinosa were subjected Soxhlet extraction and maceration method using different solvents 7 .The macerated extract was kept on the shaker for 24 hours, later it was centrifuged and the supernatant was taken for the excess solvent evaporation in laboratory conditions. After evaporation of excess solvent the crude extract was stored in refrigerator till further analysis.

\section{Phytochemical analysis of Catunaregam spinosa}

Phytochemical tests for the identification of amino acids, carbohydrates, saponins, tannins, phytosterols, alkaloids, proteins, glycosides, flavanoids and phenolic compounds were carried out for all the extracts. The present investigation was planned with an objective to establish Pharmacognostic standards and to evaluate preliminary phytochemical data that can facilitate the authentication and the isolation of the desired constituent from the correct extract ${ }^{8}$.

\section{Characterization of extract using Fourier Transform Infrared Spectrophotometer}

FTIR is the most powerful and applicable tool for identification of chemical bonds (functional groups), and their types present in sample. The wavelength which absorbed light in different variation is characteristic and predictable information for the chemical bond which can be seen in the annotated spectrum of FITR. By interpreting the infrared absorption spectrum, the chemical bonds present in molecule can be determined. Dried powder of plant sample for different solvents extracts were used in FTIR analysis with $100 \mathrm{mg} \mathrm{KBr}$ pellet as encapsulate in sample discs. The powdered plant part sample was loaded in FTIR spectroscope (Shimadzu, IR Affinity 1, Japan), with the Scanning range from 400 to $4000 \mathrm{~cm}^{-1}$ with a $4 \mathrm{~cm}$ ${ }^{1}$ resolution ${ }^{9,10}$.

\section{Anti-inflammatory activity}

\section{Carrageenan induced rat paw edema}

The anti-inflammatory activity of ethanolic extract of $C$. spinosa was determined by carrageenan induced inflammation test in hind paw of rats. Rats were fasted for 24 $\mathrm{h}$ before the commencement of experiment. Edema was induced by injecting $0.1 \mathrm{ml}$ of $1 \%(\mathrm{w} / \mathrm{v})$ carrageenan in saline. Rats were divided into different treatment groups ( $\mathrm{n}=$ 5) viz., group I (vehicle, $10 \mathrm{~mL} / \mathrm{kg}$ ), group II (indomethacin, $10 \mathrm{mg} / \mathrm{kg}$ ), group III (Ethanolic extract, $100 \mathrm{mg} / \mathrm{kg}$ ), group IV (Ethanolic extract, $200 \mathrm{mg} / \mathrm{kg}$ ). The extracts and indomethacin (IM) were suspended in 1\% CMC and administered orally by intragastric tube $1 \mathrm{~h}$ before the carrageenan injection. After the administration of the phlogistic agent, paw volume (in $\mathrm{mm}$ ) of individual rat was measured at 1,3 and $5 \mathrm{~h}^{11}$.

\section{Egg albumin induced rat paw edema}

This method has been applied in the screening of antiinflammatory activity of African spices and herbs by some researchers. Egg albumin is reported to induce inflammation in the hind paw of rats and therefore, this model was employed to evaluate the anti-inflammatory activity of extracts. Acute inflammation was induced by injecting $0.1 \mathrm{ml} / \mathrm{kg}$ of fresh egg albumin into the plantar region of the hind paw of rats. Separate sets of rats $(n=5)$ were employed for control, standard and treatment groups as described in carrageenan induced inflammation experiment. The change in paw volume $(\mathrm{mm})$ was measured up to $120 \mathrm{~min}$, at $20 \mathrm{~min}$ intervals after egg albumin injection $12,13,14$.

\section{Analgesic activity}

Analgesic activity was tested in mice (King Instt. Strain) weighing between 20-25 g with six number of animals in each group using Acetic acid induced writhing response and Hot plate response methods.

\section{Acetic acid induced writhing response}

Different groups of six mice each received orally normal distilled water $(2 \mathrm{ml} / \mathrm{kg}$ ) (i.e. control), Ethanolic extract of $C$. spinosa $(25,100$ and $500 \mathrm{mg} / \mathrm{kg})$ and Analgin (500 $\mathrm{mg} / \mathrm{kg}$ )(i.e. standard). Thirty minutes later, $0.7 \%$ acetic acid $(10 \mathrm{ml} / \mathrm{kg})$ solution was injected intraperitoneally to all the animals in different groups. The stretching episodes of individual mice were counted for 30 min post-administration of acetic acid. Analgin in a dose of $500 \mathrm{mg} / \mathrm{kg}$ orally served as standard. The formula used for computing percent inhibition was: average writhes in the control group minus writhes in the drug group divided by writhes in the control group times 100. Compounds with less than $70 \%$ inhibition are considered to have minimal antinociceptive activity ${ }^{15}$.

$$
\% \text { Inhibition }=[(\mathrm{Wc}-\mathrm{Wt}) \times 100] / \mathrm{Wc}
$$

Where, $\mathrm{Wc}=$ average number of writhes in control c group; $\mathrm{Wt}=$ average number of writhes in test $\mathrm{t}$ group

\section{Hot-plate response in mice}

Mice were retained on a hot plate having a stable temperature of $55 \pm 1^{\circ} \mathrm{C}$. The time taken for either paw licking or jumping was recorded. Each mouse was individually placed on the hot plate in order to find the animal's reaction to electrical heat-induced pain (licking of the forepaws and eventually jumping). The latency until mice showed first signs of discomfort (hind paw lifting, hind paw licking, or jumping) was recorded, before (baseline), and response was determined at 30, 60, 90,120, 150 and $180 \mathrm{~min}$ after the administration of C. spinosa $(25,100$, and $500 \mathrm{mg} / \mathrm{kg}$ ), and analgin (500 mg/kg) ${ }^{16}$.

\section{Anti-pyretic activity}

The rats were made pyretic by a sub-cutaneous injection of $20 \%$ suspension of dried Brewer's yeast in normal saline in a dose of $1 \mathrm{ml} / 100 \mathrm{~g}$. The rectal temperature was recorded by introducing a clinical thermometer about $2 \mathrm{~cm}$ deep into the rectum for the duration of one min before and $4 \mathrm{~h}$ after yeast injection. Animals showing pyrexia were selected and the drugs were administered. The rectal temperature was recorded at hourly intervals for $5 \mathrm{~h}$. Animals that indicated a rise in body temperature of at least $0.6{ }^{\circ} \mathrm{C}$ were considered eligible for carrying out further experiments.

\section{RESULTS AND DISCUSSION}

\section{Phytochemical analysis of Catunaregam spinosa}

The results of phytochemical analysis of leaves of $C$. spinosa are tabulated below in Table.1. The ethanolic extract was selected for further investigations based on the results obtained phytochemical analysis. 
Table.1: Phytochemical analysis of different extracts of Catunaregum spinosa leaves

\begin{tabular}{|c|c|c|c|c|c|c|c|c|}
\hline S. No. & Name of the constituent & (P) & (B) & (C) & (A) & (E) & (M) & $(\mathrm{Aq})$ \\
\hline 1 & Alkaloids & - & - & - & - & - & - & - \\
\hline 2 & Glycosides & - & - & 一 & + & + & + & - \\
\hline 3 & Carbohydrates & - & - & - & + & + & + & + \\
\hline 4 & Phytosterols/ Triterpenoids & + & + & + & + & + & + & - \\
\hline 5 & Proteins \& Amino acids & - & - & - & - & - & - & + \\
\hline 6 & Saponins & - & - & - & - & + & + & + \\
\hline 7 & Flavonoids & - & 一 & - & + & + & + & - \\
\hline 8 & Fixed oils \& Fats & + & - & - & - & - & - & - \\
\hline 9 & Gums/Mucilage & - & - & - & - & - & - & - \\
\hline 10 & Volatile oil & + & - & - & - & - & - & - \\
\hline 11 & Phenolics/Tannins & - & - & - & + & + & + & + \\
\hline
\end{tabular}

(P):Petroleum ether (60-80ㄷ); (B):Benzene; (C): Chloroform; (A): Acetone; (M): Methanol; (E): Ethanol; (Aq): Aqueous; +: Positive; -: Negative

\section{FTIR Spectral Analysis}

The methanolic extract of $C$. spinosa leaves showed typical absorption bands at $3295 \mathrm{~cm}^{-1}$ for a hydroxyl (-OH) group $2829 \mathrm{~cm}^{-1}$, $2413 \mathrm{~cm}^{-1}$ (for C-H stretching), $1386 \mathrm{~cm}^{-1}$ (for C-H bending), and at $1620 \mathrm{~cm}^{-1}$ for $\mathrm{C}=\mathrm{C}$ group. The ethanolic extract illustrated the observation of absorption bands at $2919 \mathrm{~cm}^{-1}$ ( for C-H stretching), $1433 \mathrm{~cm}^{-1}$ (for C-H bending) for C-H group and at 1709 $\mathrm{cm}^{-1}$, for a carbonyl group $(\mathrm{C}=0)$.

Table.2: FTIR spectral peak values and functional groups obtained for the leaf extract

\begin{tabular}{|l|l|l|}
\hline Extracts & Peak values & Functional groups \\
\hline Methanol & 1386 & C-H bending \\
& 1620 & C=C group \\
& 2413 & C-H stretching \\
& 2829 & C-H stretching \\
& 3295 & -OH group \\
\hline Ethanol & 1433 & C-H bending \\
& 1614 & C=C group \\
& 1709 & C=O carbonyl group \\
& 2919 & C-H stretching \\
& 3301 & -OH group \\
\hline
\end{tabular}

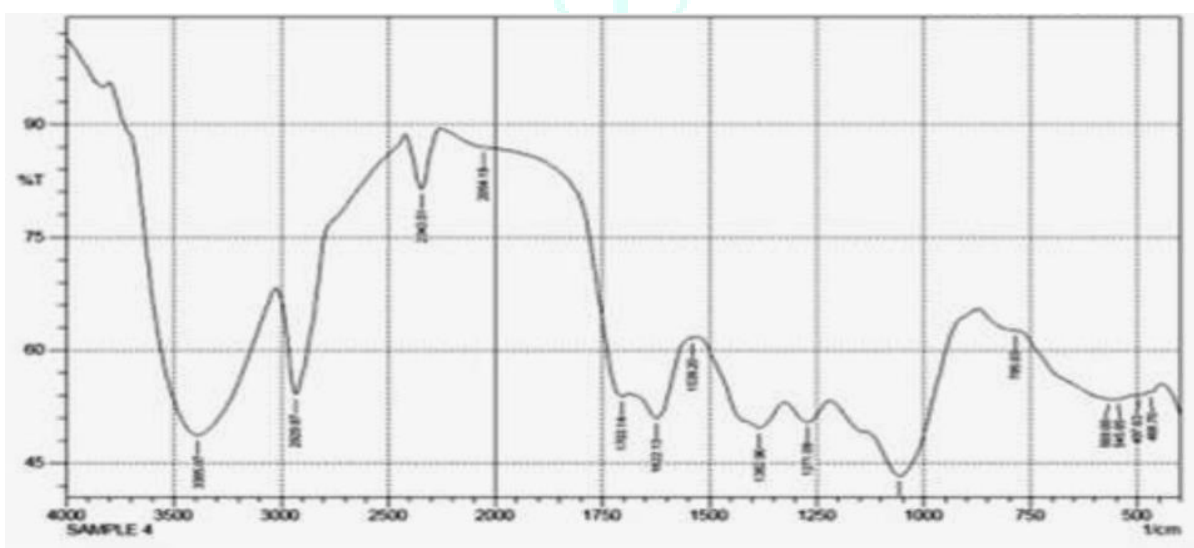

Figure.1: FTIR of $C$. spinosa Leaves in Methanol

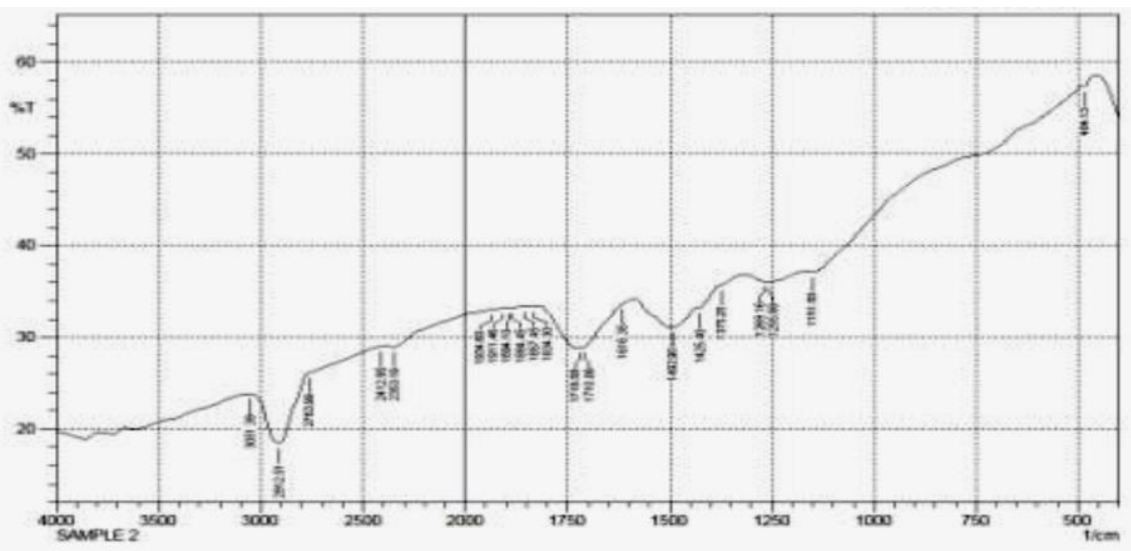

Figure.2: FTIR of $C$. spinosa Leaves in Ethanol 


\section{Anti-inflammatory activity}

Anti-inflammatory activity against carrageenan- induced inflammation

Ethanolic exract of C.spinosa at the dose of $100 \mathrm{mg} / \mathrm{kg}$ inhibited only the initial phase of inflammation, while initial as well as lateral phases of inflammation were inhibited at the dose of $200 \mathrm{mg} / \mathrm{kg}$ with percent inhibition of inflammation $31.69,35.11$ and $41.62 \%$, respectively, at 1,3 and $5 \mathrm{~h}$. Standard drug, indomethacin attenuated the inflammation at $10 \mathrm{mg} / \mathrm{kg}$ with $18.97,57.72$ and $43.53 \%$ inhibition, respectively, at 1,3 and $5 \mathrm{~h}$ (Table.3). These results were found to be dose dependent.
Anti-inflammatory activity against egg albumin- induced inflammation

To substantiate the anti-inflammatory activity of the extract, the efficacy was also studied against egg albumin-induced inflammation (Table.4). The ethanolic extract $(100 \mathrm{mg} / \mathrm{kg}$, p.o.) failed to exhibit anti-inflammatory effect $(\mathrm{p}>0.05)$ at 20 and $40 \mathrm{~min}$ time interval (initial phase) but showed significant inhibition of inflammation at 60, 80, 100 and 120 min (lateral phase) after egg albumin administration as compared to control. On the other hand, the extract at higher dose $(200 \mathrm{mg} / \mathrm{kg}$, p.o. $)$ significantly inhibited $(\mathrm{p}<0.05)$ egg albumin-induced inflammation at all time interval (initial as well as lateral phase).

Table.3: Anti-inflammatory activity of Ethanolic extract of $C$. spinosa in carrageenan-induced inflammation model

\begin{tabular}{|c|c|c|c|c|}
\hline \multirow{2}{*}{\multicolumn{2}{|c|}{\begin{tabular}{l|l} 
Treatment & $\begin{array}{l}\text { Dose } \\
\text { (mg/kg) }\end{array}$ \\
\multicolumn{2}{|c|}{ Measurement time interval $\rightarrow$}
\end{tabular}}} & \multicolumn{3}{|c|}{ Edema inhibition against carrageenan-induced inflammation (h) } \\
\hline & & 1 & 3 & 5 \\
\hline Control & & $6.23 \pm 0.13$ & $7.45 \pm 0.14$ & $6.50 \pm 0.19$ \\
\hline \multirow[b]{2}{*}{ Ethanolic extract } & 100 & $\begin{array}{l}5.10 \pm 0.21 \\
{[17.30]^{\#}}\end{array}$ & $\begin{array}{l}7.11 \pm 0.15 \\
{[4.45]^{\mathrm{ns}}}\end{array}$ & $\begin{array}{l}6.33 \pm 0.10 \\
{[3.35]^{\mathrm{ns}}}\end{array}$ \\
\hline & 200 & $\begin{array}{l}4.26 \pm 0.25 \\
{[32.06]^{\#}}\end{array}$ & $\begin{array}{l}4.83 \pm 0.18 \\
{[37.28]^{\#}}\end{array}$ & $\begin{array}{l}1.79 \pm 0.11 \\
{[43.16]^{\#}}\end{array}$ \\
\hline Indomethacin & 10 & $\begin{array}{l}5.05 \pm 0.17 \\
{[18.97]^{\#}}\end{array}$ & $\begin{array}{l}3.15 \pm 0.15 \\
{[57.72]}\end{array}$ & $\begin{array}{l}3.67 \pm 1.02 \\
{[43.53]^{\#}}\end{array}$ \\
\hline
\end{tabular}

Table.4: Anti-inflammatory activity of Ethanolic extract in egg- albumin induced inflammation model

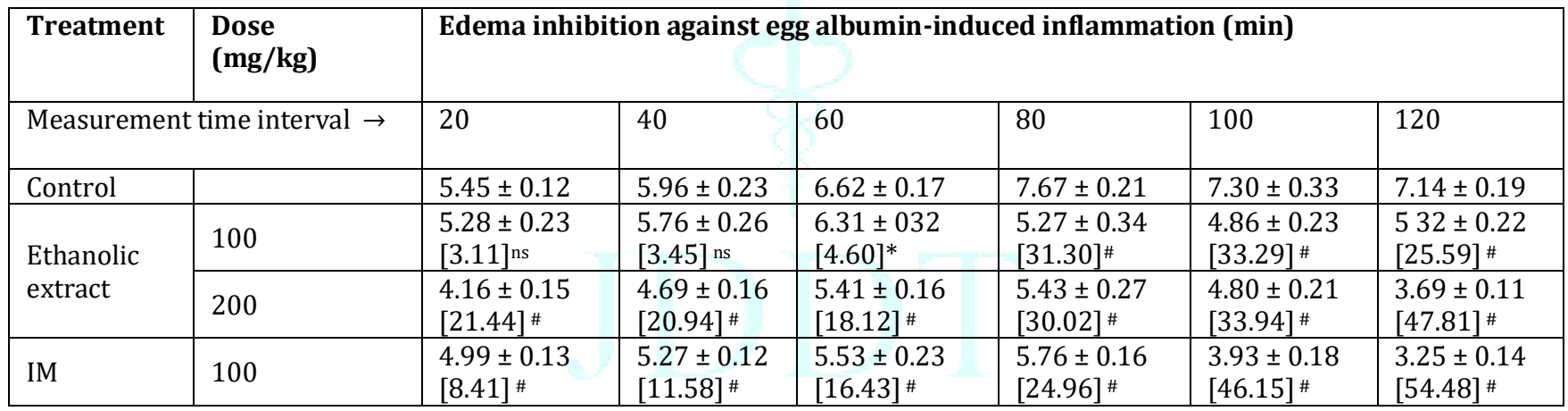

Values represent the mean \pm SEM. of five animals for each group; Values in square brackets indicatethe percentage inhibition rate of inflammation. ${ }^{*} \mathrm{p}<0.01$ and $\# \mathrm{p}<0.001$ indicate different levels of statistically significant values against control and ns stands for non significant. \% Inhibition calculated using formula: paw edema volume control-sample/control.

\section{Analgesic activity}

The compound did not show significant analgesia on stretching episodes induced by acetic acid in any dose (Table.5), whereas, it showed significant effects in the doses of 25 and $100 \mathrm{mg} / \mathrm{kg}$ on hot plate test. The analgesia produced by the former doses was for a brief period (between 60 to $90 \mathrm{~min}$ ) whereas, the effect produced by 100 $\mathrm{mg} / \mathrm{kg}$ was more prolonged and with an earlier onset comparable to the effect produced by Analgin in a dose of $500 \mathrm{mg} / \mathrm{kg}$ (Table.6).

Table.5: Effect of extract of $C$. spinosa on acetic acid induced stretching episodes in mice

(Values are Mean \pm S.E., Number of observations in parenthesis)

\begin{tabular}{|l|l|l|l|l|}
\hline Groups & Dose in mg/kg oral & Stretching episodes for 30 min & \% Inhibitory activity & P-value \\
\hline Control (6) & Distilled water & $36.33 \pm 5.77$ & --- & --- \\
\hline Analgin (6) & 500 & $3.16 \pm 1.19$ & 91.31 & $<0,001$ \\
\hline Extract (6) & 25 & $40.16 \pm 8.19$ & --- & ns \\
\hline Extract (6) & 100 & $46.16 \pm 9.33$ & --- & ns \\
\hline Extract (6) & 200 & $26.00 \pm 4.46$ & 28.44 & Ns \\
\hline
\end{tabular}


Table.6: Analgestic Acttvity of extract of $C$. spinosa on Hot plate in Mice

(Figures are Mean \pm S. E., Number of observations in parenthesis)

\begin{tabular}{|c|c|c|c|c|c|c|c|c|}
\hline \multirow[t]{2}{*}{ Groups } & \multirow{2}{*}{$\begin{array}{l}\text { Dose in } \\
\mathrm{mg} / \mathrm{kg} \text { oral }\end{array}$} & \multirow{2}{*}{$\begin{array}{l}\text { Initial } \\
\text { response time } \\
\text { (sec) }\end{array}$} & \multicolumn{6}{|c|}{ Response time in seconds after } \\
\hline & & & $30 \mathrm{~min}$ & $60 \mathrm{~min}$ & $90 \mathrm{~min}$ & $120 \mathrm{~min}$ & $150 \mathrm{~min}$ & $180 \mathrm{~min}$ \\
\hline Analgin (6) & 500 & $5.05 \pm 0.48$ & $\begin{array}{ll}7.41 & \pm \\
1.21 \mathrm{~ns} & \end{array}$ & $\begin{array}{l}14.46 \quad \pm \\
1.83 \\
p<0.001\end{array}$ & $\begin{array}{l}18.55 \quad \pm \\
1.24 \\
p<0.001\end{array}$ & $\begin{array}{l}19.14 \quad \pm \\
1.09 \\
p<0.001\end{array}$ & $\begin{array}{l}14.63 \quad \pm \\
1.87 \\
p<0.001\end{array}$ & $\begin{array}{ll}7.55 \quad \pm \\
0.88 \\
p<0.05\end{array}$ \\
\hline Extract (6) & 25 & $5.01 \pm 0.68$ & $\begin{array}{ll}6.51 & \pm \\
0.45^{\mathrm{ns}} & \end{array}$ & $\begin{array}{l}8.80 \quad \pm \\
1.20 \\
p<0.02\end{array}$ & $\begin{array}{ll}7.18 \quad \pm \\
0.29 \\
p<0.02\end{array}$ & $\begin{array}{ll}6.86 & \pm \\
1.07 \mathrm{~ns} & \end{array}$ & $\begin{array}{ll}5.96 & \pm \\
0.74 \mathrm{~ns} & \end{array}$ & $\begin{array}{ll}6.51 & \pm \\
0.64 \mathrm{~ns} & \end{array}$ \\
\hline Extract (6) & 100 & $5.11 \pm 0.32$ & $\begin{array}{l}7.20 \quad \pm \\
0.53 \\
p<0.001\end{array}$ & $\begin{array}{l}7.38 \quad \pm \\
0.96 \\
p<0.01\end{array}$ & $\begin{array}{l}7.10 \quad \pm \\
1.06 \\
p<0.01\end{array}$ & $\begin{array}{ll}6.75 \quad \pm \\
0.86 & \\
p<0.01 & \end{array}$ & $\begin{array}{ll}5.41 & \pm \\
0.91^{\mathrm{ns}} & \end{array}$ & $\begin{array}{ll}6.20 \quad \pm \\
0.94 \\
p<0.05\end{array}$ \\
\hline Extract (6) & 200 & $5.21 \pm 0.65$ & $\begin{array}{ll}7.63 & \pm \\
0.98^{\mathrm{ns}} & \end{array}$ & $\begin{array}{l}6.11 \quad \pm \\
1.11^{\text {ns }}\end{array}$ & $\begin{array}{ll}7.75 & \pm \\
1.06^{\mathrm{ns}} & \\
\end{array}$ & $\begin{array}{l}6.48 \quad \pm \\
0.73^{\text {ns }}\end{array}$ & $\begin{array}{ll}6.35 & \pm \\
0.41^{\mathrm{ns}} & \end{array}$ & $\begin{array}{ll}5.43 & \pm \\
0.55^{\text {ns }} & \\
\end{array}$ \\
\hline
\end{tabular}

ns stands for non significant.

\section{Antipyretic activity}

There was no 'antipyretic effect observed in this model of experiment in any of the doses employed (Table.7).

Table.7: Effect of extract of $C$. spinosa On Brewer's Yeast Induced Pyrexia in Rats

(Values are Mean \pm S. E., Number of animals in parenthesis)

\begin{tabular}{|c|c|c|c|c|c|c|c|c|}
\hline \multirow[t]{2}{*}{ Groups } & \multirow{2}{*}{$\begin{array}{l}\text { Body } \\
\text { Weight } \\
\text { (in g) }\end{array}$} & \multirow{2}{*}{$\begin{array}{l}\text { Fasting rectal } \\
\text { temp. } \\
\text { (o) }\end{array}$} & \multirow{2}{*}{$\begin{array}{l}\text { Initial } \\
\text { Pyrexia }\end{array}$} & \multicolumn{5}{|c|}{ Mean rectal temperature in ${ }^{\circ} \mathrm{F}$ at } \\
\hline & & & & $1^{\text {st }} \mathbf{h}$ & $2^{\text {nd }} h$ & $3^{\text {rd }} \mathbf{h}$ & $4^{\text {th }} h$ & $5^{\text {th }} \mathbf{h}$ \\
\hline Control(6) & $\begin{array}{l}131 \quad \pm \\
6.57\end{array}$ & $99.45 \pm 0.05$ & $\begin{array}{l}102.75 \pm \\
0.29\end{array}$ & $\begin{array}{l}102.95 \pm \\
0.13\end{array}$ & $\begin{array}{l}103.10 \pm \\
0.17\end{array}$ & $\begin{array}{l}103.70 \pm \\
0.33\end{array}$ & $\begin{array}{l}103.85 \pm \\
0.20\end{array}$ & $\begin{array}{l}103.26 \pm \\
0.27\end{array}$ \\
\hline $\begin{array}{c}\text { Paracetamol } 500 \\
\mathrm{mg} / \mathrm{kg}(6)\end{array}$ & $\begin{array}{l}163.75 \pm \\
8.50\end{array}$ & $99.30 \pm 0.15$ & $\begin{array}{l}102.35 \pm \\
0.24\end{array}$ & $\begin{array}{l}100.85^{*} \pm \\
0.11\end{array}$ & $\begin{array}{l}99.70^{*} \pm \\
0.21\end{array}$ & $\begin{array}{l}100.20^{\#} \pm \\
0.63\end{array}$ & $\begin{array}{l}101.25^{\#} \pm \\
0.25\end{array}$ & $\begin{array}{l}101.80 \pm \\
0.21^{\text {ns }}\end{array}$ \\
\hline $\begin{array}{c}\text { Extract } \\
25 \mathrm{mg} / \mathrm{kg}(6)\end{array}$ & $\begin{array}{l}148.75 \pm \\
13.90\end{array}$ & $99.30 \pm 0.23$ & $\begin{array}{l}102.80 \pm \\
0.25\end{array}$ & $\begin{array}{l}102.50 \pm \\
3.28^{\mathrm{ns}}\end{array}$ & $\begin{array}{l}102.00 \pm \\
3.28^{\mathrm{ns}}\end{array}$ & $\begin{array}{l}102.85 \pm \\
0.26^{\mathrm{ns}}\end{array}$ & $\begin{array}{l}103.85 \pm \\
0.65^{\mathrm{ns}}\end{array}$ & $\begin{array}{l}102.25 \pm \\
0.41^{\text {ns }}\end{array}$ \\
\hline $\begin{array}{c}\text { Extract } \\
100 \mathrm{mg} / \mathrm{kg} \mathrm{(6)}\end{array}$ & $\begin{array}{l}111.25 \pm \\
9.43\end{array}$ & $99.05 \pm 0.22$ & $\begin{array}{l}102.60 \pm \\
0.29\end{array}$ & $\begin{array}{l}103.00 \pm \\
0.25^{\mathrm{ns}}\end{array}$ & $\begin{array}{l}103.40 \pm \\
0.14^{\mathrm{ns}}\end{array}$ & $\begin{array}{l}102.00 \pm \\
0.80^{\mathrm{ns}}\end{array}$ & $\begin{array}{l}103.05 \pm \\
0.17 \mathrm{~ns}\end{array}$ & $\begin{array}{l}103.60 \pm \\
0.42^{\mathrm{ns}}\end{array}$ \\
\hline $\begin{array}{c}\text { Extract } \\
200 \mathrm{mg} / \mathrm{kg}(6)\end{array}$ & $\begin{array}{l}125.00 \pm \\
8.89\end{array}$ & $98.90 \pm 0.17$ & $\begin{array}{l}101.85 \pm \\
0.62\end{array}$ & $\begin{array}{l}102.50 \pm \\
0.97 \mathrm{~ns}\end{array}$ & $\begin{array}{l}102.20 \pm \\
0.39^{\mathrm{ns}}\end{array}$ & $\begin{array}{l}101.95 \pm \\
1.01^{\mathrm{ns}}\end{array}$ & $\begin{array}{l}102.50 \pm \\
0.4^{\mathrm{ns}}\end{array}$ & $\begin{array}{l}101.10 \pm \\
2.03^{\mathrm{ns}}\end{array}$ \\
\hline
\end{tabular}

\section{CONCLUSION}

The multifunctional properties of $C$. spinosa exposed in previous studies about its antioxidant and anticancer activities might be useful in explaining ethnopharmacological claim of its therapeutic potential in inflammation, pain and fever, showing no signs of oral toxicity.

The extract of C. spinosa showed significant antiinflammatory effect both in exudative and proliferative phases of inflammation. In carrageenin induced edema, the effect produced by the dose of $100 \mathrm{mg} / \mathrm{kg}$ was little lesser than Indomethacin in the dose of $10 \mathrm{mg} / \mathrm{kg}$ with further higher increase in anti-inflammatory activity with higher dose of $200 \mathrm{mg} / \mathrm{kg}$. In case of egg-albumin induced inflammation, dose of $200 \mathrm{mg} / \mathrm{kg}$ showed anti-inflammatory activity which was comparable to Indomethacin $(10 \mathrm{mg} / \mathrm{kg})$.

The compound did not show significant analgesia in chemical writhing test whereas, on hot-plate, significant effect was observed in the doses of 25 and $100 \mathrm{mg} / \mathrm{kg}$. The analgesia produced by the former doses was for a brief period (between 60 to $90 \mathrm{~min}$ ) whereas, the effect produced by 100 $\mathrm{mg} / \mathrm{kg}$ was more prolonged and with an earlier onset comparable to the effect produced by Analgin in a dose of $500 \mathrm{mg} / \mathrm{kg}$.

The compound is devoid of antipyretic effect in this model of experiment. The maximum anti-inflammatory and analgesic activities are almost around the dose of $200 \mathrm{mg} / \mathrm{kg}$ which certainly may make it interesting to study further in detail therefore it could be clinically tried.

\section{REFERENCES}

1. Pallab naity,Dipak Mishra et al.,Biological activities of crude extracts and chemical constituents of Bael, Aegle marmelos (L.), Indian Journal of experimental biology : November 2009, 47, pp. 849-861.

2. Vaidya. V. M. Gogte, Ayurvedic Pharmacology and Therapeutic Uses of medicinal Plants(Dravyaguna vignyan) Part II, medicinal plants, Plant no.(87), First English Edition, Bhartiya Vidya Bhavan, Oct 2000, Pg 454.

3. Kirtikar K.R., Basu B.D. Indian Medicinal Plants. Panni office,Bhuwaneswari Ashrama, Bahadurganj, Allahabad. (1991) 648-652.

4. Agrawal SS, Singh VK, Immuno modulators-A review of studies on Indian medicinal plants and synthetic peptides, Part- 1 , Medicinal plants, Proc Indian Natl Sci Acad, 62, 1999, 179-204.

5. Sharma PC, Yelne MB, Denis JJ, Data base on Medicinal plants used in Ayurveda, Central Council for Research in Ayurveda \& Siddha, 2000, 380-383.

6. Iyengar MA, Bibliography of Investigated Indian Medicinal Plants, (1950-1975), Manipal, Manipal Power Press, 1976, 1 144.

7. World Health Organisation. 1998; Quality Control Methods for Medicinal Plant Materials, WHO, Geneva. 
8. Harborne JB. Phytochemical methods, Chapman and Hall, London (1998), Edn 3, 90 - 203.

9. Yang J, Yen HCE, Early Salt Stress Effects on the Changes in Chemical Composition in Leaves of Ice Plant and Arabidopsis, A Fourier Transform Infrared Spectroscopy Study, Plant Physiology, 130, 2002, 1032-1042.

10. Martín JA, Solla A, Woodward S, Gil L, Fourier transforminfrared spectroscopy as a new method for evaluating host resistance in the Dutch elm disease complex, Tree Physiology, 25, 2005, 1331-1338.

11. Winter C.A., Risley E.A., Nuss G.W., Proc. Soc. Exp. Biol. Med. 111, 544 (1962).

12. Otimenyin, S.O., Uguru, M.O., Auta, A., 2008. Anti-inflammatory and nalgesic activities of Cassia goratensis and Sacrocephalus esculentus extracts. J. Herbs Spices Med. Plants 13, 59-67.
13. Chinasa, E.C., Ifeoma, I.A., Obodoike, E.C., Chhukwuemeka, E.S., 2011. Evaluation of anti-inflammatory property of the leaves of Sansevieria liberica ger. and labr. (fam: Dracaenaceae). Asian Pac J Trop Med 4, 791-795.

14. Winter C.A., Risley E A., Nuss G.V., J. Pharmacol. Exp. Ther. 141, 369 (1963).

15. Turner R. A. (1965a). Non-narotic analgesics. In Screening Methods in Pharmacology. Vol. 1, pp. 114-115, New York : Academic Press.

16. Eddy, N.B. and Leimbach, D.J., (1953) Synthetic analgesics. II. Dithie-nylbutenyl- and dithienylbutylamines. Journal of Pharmacology and Experimental Therapeutics, 107, 385-393. 